\title{
Analysis of Precipitation and Temperature Variability over Central Africa (1901-2015)
}

\author{
Yaw A. Twumasi ${ }^{*}$, Edmund C. Merem², John B. Namwamba1, Tomas Ayala-Silva ${ }^{3}$, \\ Kamran Abdollahi' ${ }^{1}$, Ronald Okwemba ${ }^{1}$, Onyumbe E. Ben Lukongo4, Caroline 0. Akinrinwoye ${ }^{1}$, \\ Joshua Tate ${ }^{1}$, Kellyn La Cour-Conant ${ }^{1}$
}

\footnotetext{
${ }^{1}$ Department of Urban Forestry and Natural Resources, Southern University and A\&M College, Louisiana, USA

${ }^{2}$ Department of Urban and Regional Planning, Jackson State University, Jackson, Mississippi, USA

${ }^{3}$ USDA-ARS Tropical Agriculture Research Station, Mayaguez, Puerto Rico

${ }^{4}$ Department of Public Policy, Southern University and A\&M College, Nelson Mandela College of Government and Social Sciences, Baton Rouge, Louisiana, USA

Email: ‘yaw.twumasi@subr.edu, ^yaw.twumasi@gmail.com
}

How to cite this paper: Twumasi, Y.A. Merem, E.C., Namwamba, J.B., Ayala-Silva, T., Abdollahi, K., Okwemba, R., Lukongo, O.E.B., Akinrinwoye, C.O., Tate, J. and La Cour-Conant, K. (2020) Analysis of Precipitation and Temperature Variability over Central Africa (1901-2015). Atmospheric and Climate Sciences, 10, 220-239. https://doi.org/10.4236/acs.2020.102012

Received: February 3, 2020

Accepted: April 20, 2020

Published: April 23, 2020

Copyright $\odot 2020$ by author(s) and Scientific Research Publishing Inc. This work is licensed under the Creative Commons Attribution International License (CC BY 4.0).

http://creativecommons.org/licenses/by/4.0/ (c) (i) Open Access

\begin{abstract}
Africa is already experiencing the impact of climate change. Some of the manifestations of climate change in Africa are, changing weather patterns resulting in, flooding and drought. Temperature change has impacted health, livelihoods, productivity of food, availability of water, and state of security. This study examines the long-term climate variations in Central African Countries (Gabon, Cameroon, Republic of Congo, Central Africa Republic, Chad and Democratic Republic of Congo) for the period 1901 to 2015, and then investigates the possible influence of increases in greenhouse gas concentrations. To investigate climate patterns and trends in the Central African Countries, precipitation and temperature were analyzed on annual time scales using data collected from the World Bank Group Climate Change Knowledge Portal. Data was further aggregated using annual average blocks of 10 years. Linear and polynomial regression was performed. Also, linear time series slopes were analyzed to investigate the spatial and temporal trends of climate variability in Central African countries. Results of the analyses indicated that the mean annual temperature and precipitation records in some of the Central African Countries had both warming and cooling trends over the study period from 1901 to 2015. For example, differences between the maximum and the minimum rainfall data for Democratic Republic of Congo, Cameroon and Gabon were $13 \mathrm{~mm}, 13 \mathrm{~mm}$ and $11.1 \mathrm{~mm}$, which corresponded to $11.04 \%$, $10.03 \%$ and $10.44 \%$ respectively. The study also found the temperature of Chad to have significantly risen from 1901 to 2015 by almost 20\%, while its rainfall's variation was limited. Although the variation in rainfall in Chad was not dramatic, the temperature per 10 year rose by almost $20 \%$. Chad's tem-
\end{abstract}


perature rose according to a cubic model from about $24.5^{\circ} \mathrm{C}$ to just below $27^{\circ} \mathrm{C}$ during the period 1901-1940. This was followed by a brief drop between 1940 and 1960. From 1960 to 2015 it rose according to the model to almost $28^{\circ} \mathrm{C}$. By 2040 the temperature is expected to reach about $29.5^{\circ} \mathrm{C}$ if this trend continues. Gabon was found to be the wettest country in Central Africa. Between 1901 and 1960, its average rainfall rose from about $144 \mathrm{~mm}$ to a maximum of approximately $160 \mathrm{~mm}$. It had a general average rainfall/10 year's increase from 1901 to 2015 . The paper concludes by outlining policy recommendations in the form of improving national and regional environmental policies and regulations in the region, community involvement in decision making processes both at local and the national levels so as to contribute their input in the daily management of the forest resources, poverty alleviation in the region as well as building regional information system (RIS) incorporating Geographic Information System (GIS), remote sensing and other environmental and socio-economic data to help reduce anthropogenic emissions of greenhouse gases.

\section{Keywords}

Temperature, Rainfall, Climate Variability, Linear and Polynomial Regression, Central African Countries

\section{Introduction}

Climate is among important drivers of ecosystems' health, their compositions and other earth systems. Rainfall, atmospheric pressure, temperature and humidity are among the variables that control weather and climate respectively. Climate describes statistical variations of components of weather over time spanning from months to many centuries [1]. In the last two decades, there have been global concerns about the degradation of the world's ecosystems because of its attendant impact on greenhouse gases. The loss of biodiversity fueled by anthropogenic influences has been attributed in part to increased levels of greenhouse gases [2] [3] [4] [5] [6]. These changes in greenhouse gases and aerosols, taken together, are projected to lead to regional and global changes in temperature, precipitation, and other climate variables-resulting in global changes in soil moisture, an increase in global mean sea level, and prospects for more severe extreme high-temperature events, floods, and droughts in some places [5] [7]-[12]. Climate variations in temperatures and precipitations have been examined in different regions of the world over recent decades e.g. [13] [14] [15] [16] [17]. A study by Rosenbluth et al. [18] in Chile and Argentina reported variations in temperature due to influence of El Ninõ, Southern Oscillation on surface temperature along the Pacific South American coast $18^{\circ} \mathrm{S}$ to $53^{\circ} \mathrm{S}$. Whitfield et al. [19] analyzed monthly temperature and precipitation time series for several hundred weather stations across Canada. Results showed variations in temperature and precipitation at different temporal and spatial scales. They further con- 
cluded that, differences observed in temperature and precipitation could have been the result of variations in atmospheric circulations.

Global changes especially warming could impact regional climates, especially rainfall patterns in the long-term. Local activities such as modification of land cover and disruption of local and regional hydrology could also impact climates [20]. Among the physical parameters of climate, temperature and rainfall play roles of paramount importance [21] since conditions of the environment in different places of regions impacting agricultural productivity depend on them [22]). The warming earth alters temperature, rainfall and other patterns of weather and climate. This poses threats to human health, plant and animal lives respectively. This paper examines rainfall and temperature data in central African countries in order to determine existing patterns in variation of the data.

\section{Methodology}

\subsection{The Study Area}

Central Africa is a region of the African continent comprising of Angola, Burundi, Cameroon, the Central African Republic, Chad, the Democratic Republic of the Congo, the Republic of the Congo, Equatorial Guinea, Gabon, Rwanda, and São Tomé and Príncipe. This study focused on data from Democratic Republic of Congo (DRC), Republic of Congo, Cameroun, Chad and Gabon (Figure 1). The area is home to the world's natural rainforests. As the region embarks

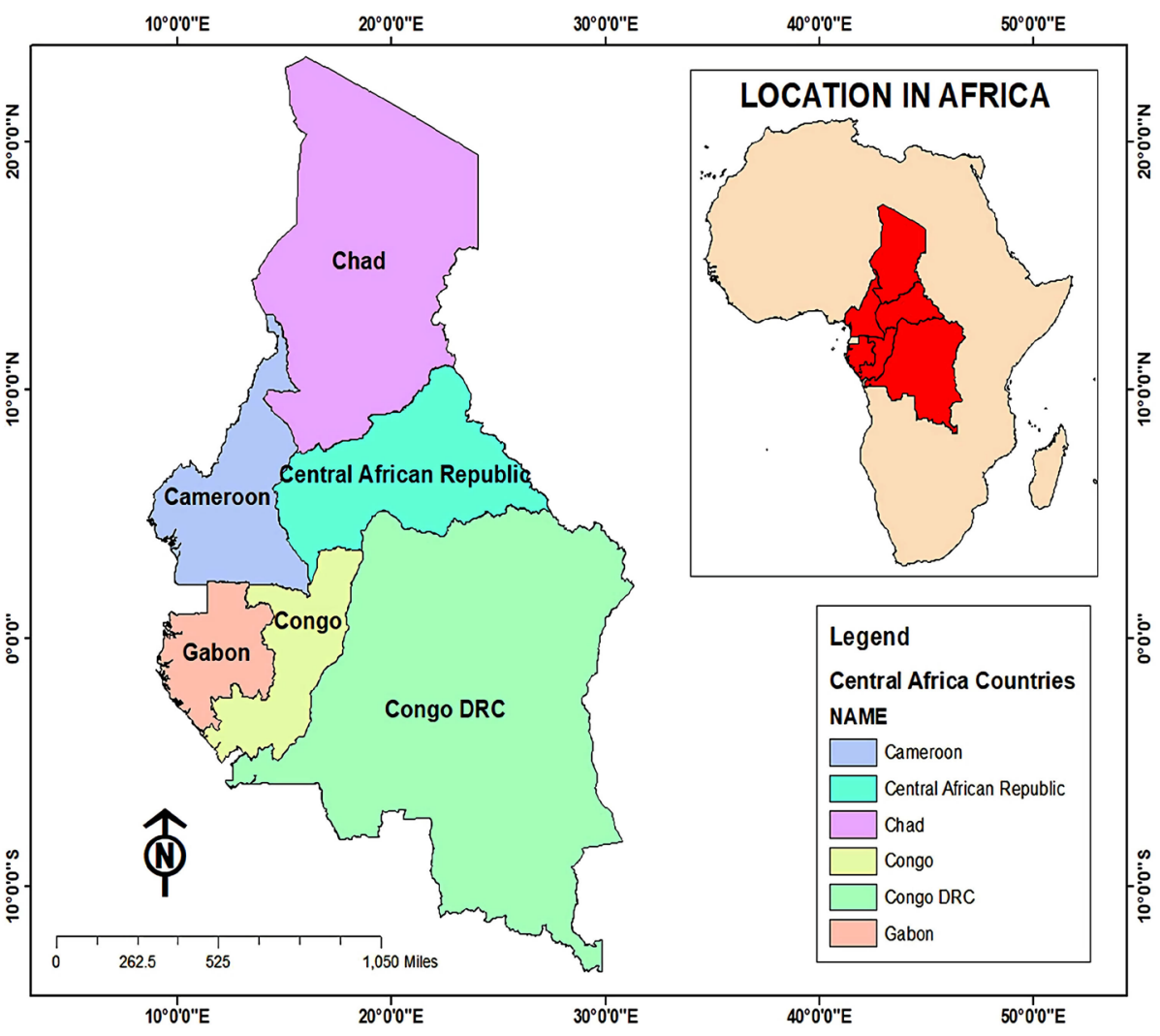

Figure 1. The study area. 
upon an unprecedented phase of economic expansion, it faces several environmental challenges fueled partly by the pressures caused by human activities through economic activities, such as housing development, and road construction for transportation, economic development and demographic changes. In the last few decades, the region has been experiencing increasing resources degradation, fueling climate change [23]. Human activities inside these countries, for example, deforestation and degradation of forest resources, large scale and illegal mining, urbanization, slash and burn agriculture, resulting from shifting cultivation and uncontrolled exploitation to satisfy the needs of both the local and nonlocal populations are some of the major issues confronting the region. Rapidly growing population and poverty are stretching the resources of the basin beyond its carrying capacity.

\subsection{Data Acquisition and Processing}

For this study, temporal analysis of rainfall data from, the Democratic Republic of Congo, Cameroun, Gabon, Republic of Congo, Central African Republic and Chad were used. Rainfall and temperature data sets of 1950-2015 for the stated countries were downloaded from World Bank Group Climate Change Knowledge Portal for Development Practitioners and Policy Makers [24]. Before modeling, rainfall and temperature trends for each country, tables for 10-year blocks were made. Table 1 illustrates the data used to compute the average monthly rainfall for the years 1911 to 1920 , which is shown as $124.44 \mathrm{~mm}$ in the table. All the rainfall data collected from January 1911 to December 1920 was summed up and divided by the total number of months, yielding rainfall per month per 10 years. Microsoft Excel spread sheet was used to compute the averages. This procedure was used to compute all entries in Table 2, for Democratic Republic of Congo. The same procedure was also carried out for the other central African countries to yield data illustrated in Table 3 and Table 4 for Cameroun and Gabon respectively.

Table 1. Rainfall data mm/10 years table (1911-1920).

\begin{tabular}{cccccccccccc}
\hline Month & Rainfall & Year & Month & Rainfall & Year & Month & Rainfall & Year & Month & Rainfall & Year \\
\hline January & 110.3 & 1911 & June & 42.2 & 1912 & December & 140 & 1914 & May & 122.9 & 1916 \\
February & 138.7 & 1911 & July & 55.2 & 1912 & January & 103.8 & 1915 & June & 63.1 & 1916 \\
March & 157 & 1911 & August & 80.4 & 1912 & February & 110.8 & 1915 & July & 41 & 1916 \\
April & 141.9 & 1911 & September & 141.1 & 1912 & March & 153.5 & 1915 & August & 84.4 & 1916 \\
May & 111 & 1911 & October & 145.8 & 1912 & September & 135 & 1916 & February & 104.1 & 1918 \\
June & 59.5 & 1911 & November & 191.9 & 1912 & October & 177.9 & 1916 & March & 175.1 & 1918 \\
July & 62.1 & 1911 & December & 142.1 & 1912 & November & 189.2 & 1916 & April & 156.6 & 1918 \\
August & 77.6 & 1911 & January & 112.2 & 1913 & December & 171.6 & 1916 & May & 92.9 & 1918 \\
September & 137.7 & 1911 & February & 126.4 & 1913 & January & 153.3 & 1917 & June & 68.8 & 1918 \\
October & 177 & 1911 & March & 148.4 & 1913 & February & 143.8 & 1917 & July & 60.4 & 1918 \\
\hline
\end{tabular}




\section{Continued}

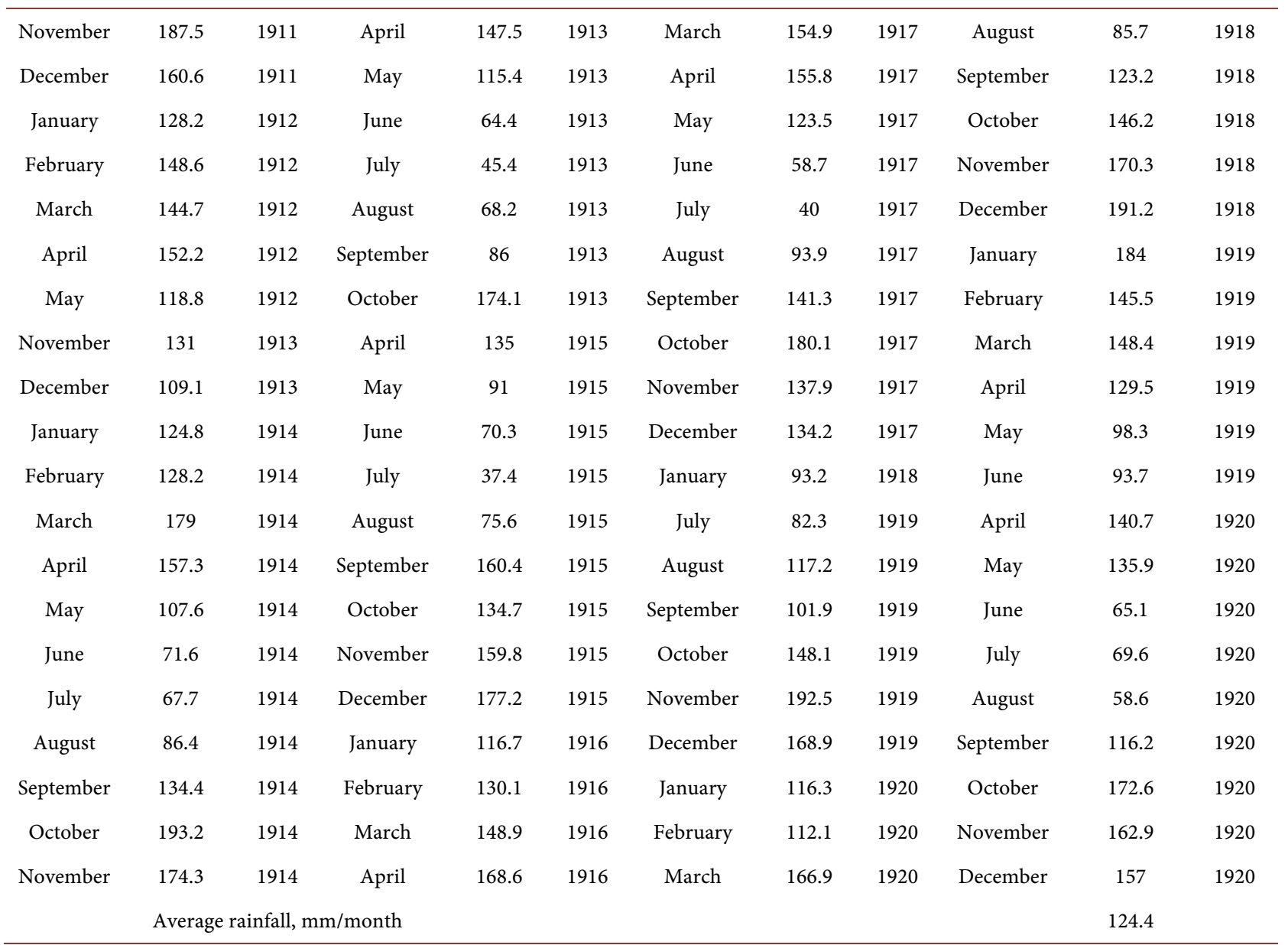

Table 2. Average monthly rainfall $\mathrm{mm} / 10$ years for Democratic Republic of Congo (DRC).

\begin{tabular}{cc}
\hline Average rainfall $\mathrm{mm} / 10$ years (Democratic Republic of Congo) \\
\hline Years after 1900 & Average rainfall (mm) \\
\hline 1901 & 122.8631 \\
1910 & 126.487 \\
1920 & 124.3271 \\
1940 & 126.6208 \\
1950 & 126.0523 \\
1960 & 128.9018 \\
1970 & 132.4034 \\
1980 & 125.5405 \\
1990 & 127.811 \\
2000 & 119.2098 \\
2010 & 124.8244 \\
2015 & 127.3143 \\
&
\end{tabular}


Table 3. Average monthly rainfall $\mathrm{mm} / 10$ years for Cameroun.

\begin{tabular}{lc}
\hline Year & Average rain/10 years \\
\hline 1901 & 137.8247 \\
1910 & 137.8247 \\
1920 & 137.0419 \\
1930 & 135.0912 \\
1940 & 136.6843 \\
1950 & 134.2571 \\
1960 & 133.1015 \\
1970 & 140.1571 \\
1980 & 139.6232 \\
1990 & 133.0645 \\
2000 & 127.3796 \\
2010 & 134.3287 \\
2015 & 130.0457 \\
\hline
\end{tabular}

Table 4. Average monthly rainfall $\mathrm{mm} / 10$ years for Gabon.

\begin{tabular}{lc}
\hline Year & Average rain/10 years \\
\hline 1901 & 144.4524 \\
1910 & 146.2408 \\
1920 & 144.9641 \\
1930 & 150.4393 \\
1940 & 148.9023 \\
1950 & 152.9573 \\
1960 & 159.5338 \\
1970 & 156.1968 \\
1980 & 150.1271 \\
1990 & 150.6118 \\
2000 & 152.3903 \\
2010 & 151.0454 \\
2015 & 155.4274 \\
\hline
\end{tabular}

To develop models that identify trends in rainfall and temperature data sets, aggregation of data using batches of 10 years was adopted for all the countries. In the modelling of the variations between variables in atmospheric data, regression was used.

The models for average rainfall and temperature based on data sets of 10 consecutive years were modeled based on the following respective formulations.

$$
\text { Rainfall, } R \propto f(t)
$$


For cubic model,

$$
R=A_{n+1} t^{n}+A_{n} t^{n-1}+A_{n-1}+t^{n-2}+A_{n-2}
$$

For quadratic model,

$$
R=A_{n+1} t^{n}+A_{n} t^{n-1}+A_{n-1}+t^{n-2}+A_{n-2}
$$

For linear model,

$$
R=A t+B
$$

where, $R$ is the average rainfall based on 10 consecutive years in $\mathrm{mm} /$ year, $n$ is the polynomial index and $t$ is time in years. $A_{1}, A_{2}, A_{3}$ and $\mathrm{B}$ are constants.

$$
\text { Temperature } T \propto f(t)
$$

For cubic model,

$$
T=A_{n+1} t^{n}+A_{n} t^{n-1}+A_{n-1}+t^{n-2}+A_{n-2}
$$

For quadratic model,

$$
T=A_{n+1} t^{n}+A_{n} t^{n-1}+A_{n-1}+t^{n-2}+A_{n-2}
$$

where, $T$ is the average temperature based on 10 consecutive years in ${ }^{\circ} \mathrm{C} /$ year, $\mathrm{n}$ is the polynomial index and $t$ is time in years. $A_{1}, A_{2}$ and $A_{3}$ are constants.

Statistical software (SPSS, Microsoft Excel data analysis toolkit, etc.) was used to fit data and build models. The strength of model developed was based on the magnitude of the coefficients of correlations between variables ( $\mathrm{R}$ square), which ranged from 0 to $1.0(0 \%-100 \%)$.

A model was accepted if the corresponding coefficient of correlation was close to $100 \%$. Linear and curvilinear modellings were applied depending on the correlations between data pairs, which attempts to develop single models for data sets spanning from 1901 to 2015 yielded models of low coefficients of correlations for most data sets. To develop models that were more representative of the data sets, illustrating the rises and falls in environmental data, data aggregates from time spans shorter than the entire data collection range of time (1901-2015) were used in modeling. Modeling for rainfall trends was carried out for, the Democratic Republic of Congo (DRC), Gabon and Cameroun since the difference between their maxima and minima rainfall data was at least $10 \%$. Only Chad had a percentage change of temperature higher than $15 \%$. Hence temperature change was only analyzed for Chad. The modeling processes and corresponding results for each of the countries are discussed as follows.

\section{Results and Discussion}

\section{Democratic Republic of Congo (DRC)}

\section{Rainfall}

The data used in modeling rainfall for the Democratic Republic of Congo (DRC) is presented in Table 2 .

The difference between the maximum and the minimum rainfall data was 13 $\mathrm{mm}$. The percentage rise from the minimum to maximum temperature was 
$((132.4-119.2) / 119.2) \times 100=11.04 \%$. Regression analysis was used to model the Democratic Republic of Congo's average monthly rainfall data per consecutive 10 years versus years. The data from 1901 to 1940 was fitted into a third order polynomial equation. The general average rainfall trend from 1901 to 1940 is represented by a gradual rise from about $123 \mathrm{~mm}$ in 1901 to a maximum quantity of $126 \mathrm{~mm}$ in 1910 (Figure 2). It then dropped gradually to a minimum value of $124 \mathrm{~mm}$ in 1930 . It then gradually rose to $126.5 \mathrm{~mm}$ in 1940 . The model is represented by the equation illustrated in Figure 2. This equation explains about $91 \%$ of the variation in average rainfall data for the specified span of time.

A polynomial function of order 3 was used to model rainfall data from 1940 to 1980 by curve fitting. The equation and the curve are given and illustrated in Figure 3.

The average rainfall/10 years dropped from about $127 \mathrm{~mm}$ in 1940 to a local minimum of $125 \mathrm{~mm}$ in 1945 . It then rose to a local maximum of about132 $\mathrm{mm}$ in 1970, and then gradually dropped to a value between $125 \mathrm{~mm}$ and $126 \mathrm{~mm}$ in

\section{Average monthly rainfall $\mathrm{mm} / 10$ years versus years,DRC (1901-1940)}

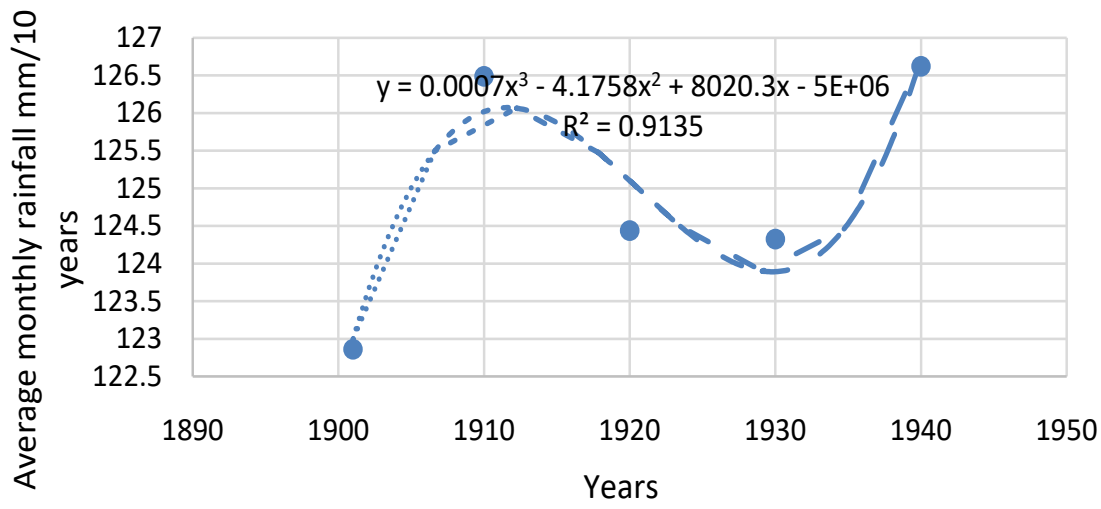

Figure 2. Variation of average monthly rainfall mm/10 years' aggregates, DRC (1901-1940).

\section{Average monthly rainfall $\mathrm{mm} / 10$ years (DRC 1940-1980)}

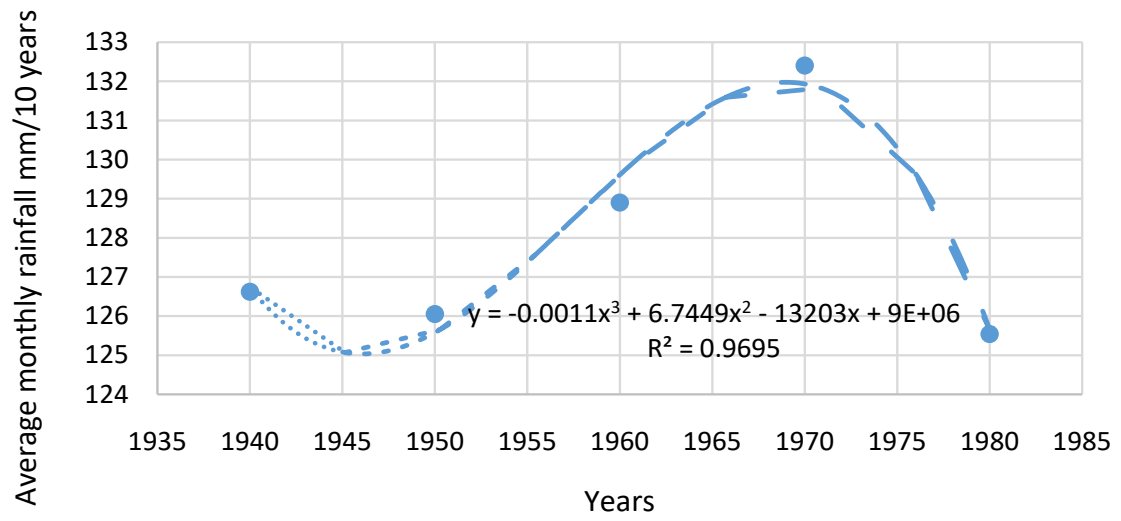

Figure 3. Variation of average monthly rainfall mm/10 years' aggregates, DRC (1940-1980). 
1980 (Figure 3 ). This equation explains about $97 \%$ of the variation in average rainfall/10 data for the specified span of time $\left(R^{2}=0.9605\right)$.

The average rainfall data/10 consecutive years for the time span 1980-2015 was fitted into a third order polynomial equation. The equation for the trend and the curve is illustrated in Figure 4. According to the model, the average rainfall per 10 years rose from an initial magnitude of approximately $126 \mathrm{~mm}$ in 1980 , to approximately $128 \mathrm{~mm}$ in 1985 . It then dropped gradually to a local minimum of about $120 \mathrm{~mm}$ in 2005 . It then rose gradually to $128 \mathrm{~mm}$ by 2015 . For this model, $R$ squared is 0.688 . Hence, the model explains or represents about $69 \%$ of the data. Stronger models for the data for 1980-2015 were developed by modeling data sets for 1980-2000 and 2000-2015 separately to yield the models illustrated in Figure 5 and Figure 6 respectively.

\section{Cameroun}

The difference between the maximum and the minimum rainfall data for Cameroun's data is $13 \mathrm{~mm}$. Hence, the percentage rise from the minimum to maximum

Average monthly rainfall $\mathrm{mm} / 10$ years versus years (DRC 1980-2015)

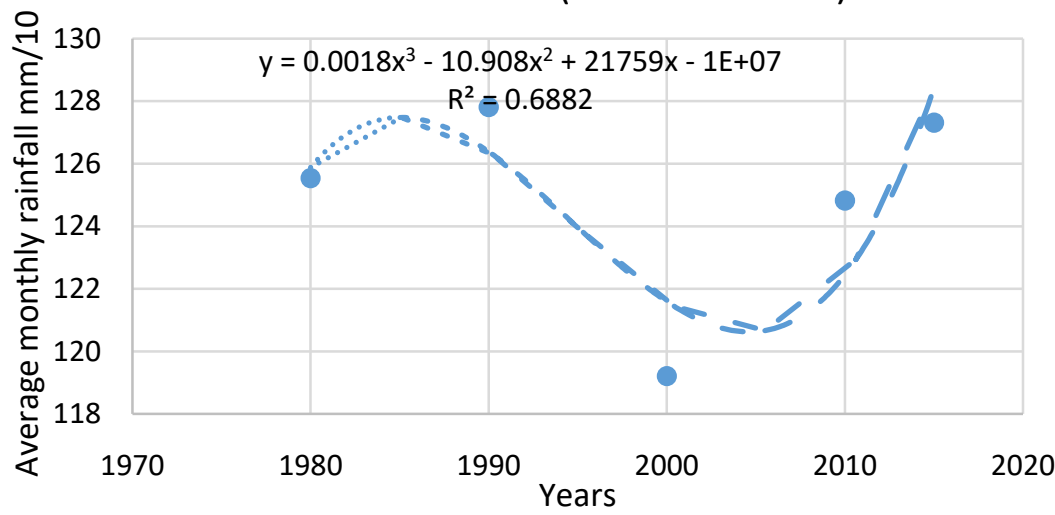

Figure 4. Variation of average monthly rainfall mm/10 years' aggregates, DRC (1980-2015).

Average monthly rainfall $\mathrm{mm} / 10$ years versus years (DRC 1980-2000)

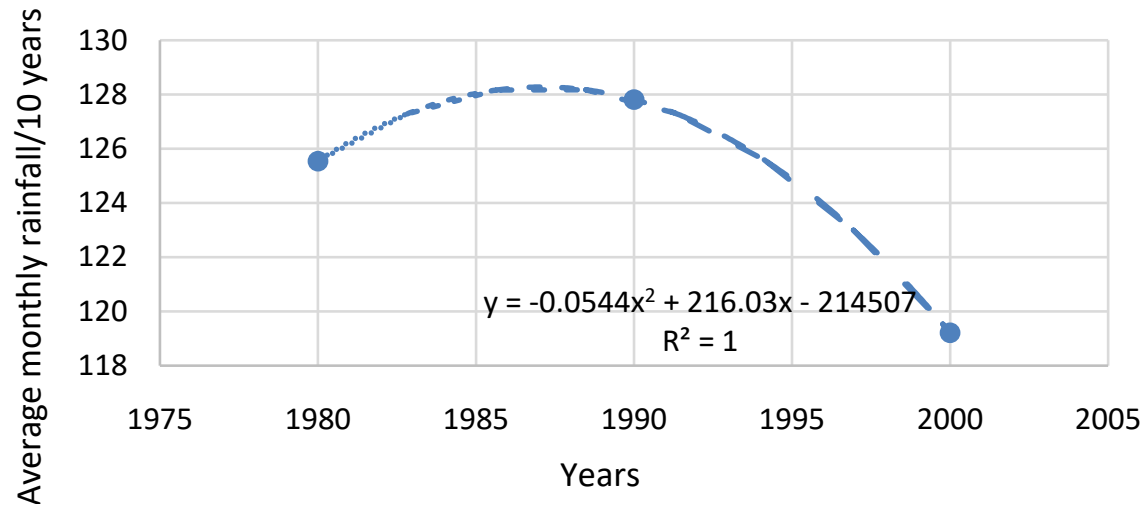

Figure 5. Variation of average rainfall, mm per 10 years' aggregates, DRC (1980-2000). 


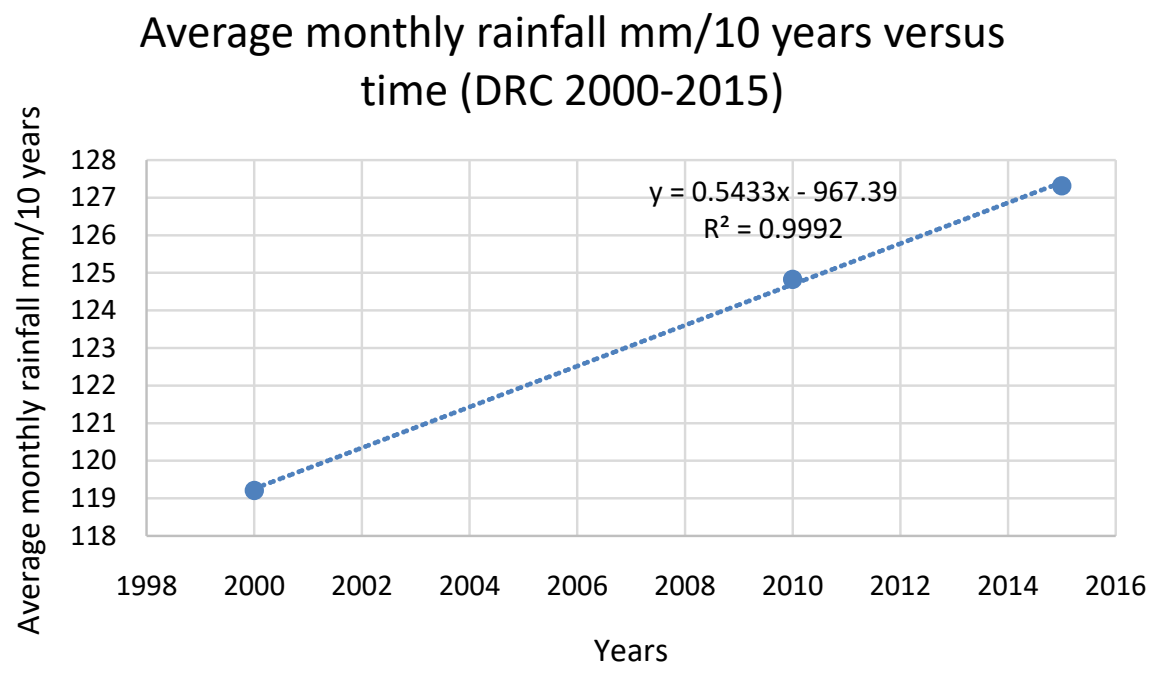

Figure 6. Variation of average rainfall per 10 years' aggregates, DRC (2000-2015).

temperature was $((140.157-127.38) / 127.38) \times 100=10.03 \%$.The data used in modeling rainfall Cameroun is presented in Table 3.

The mean rainfall data per10 consecutive years was fitted to a cubic equation. The following model was developed. $y=-2 \mathrm{E}-05 x^{3}+0.1287 x^{2}-250.73 x+$ 162992 (Figure 7).

Where, $y$ is the average rainfall based on every 10 consecutive years in $\mathrm{mm} /$ year and $x$ is time in years.

This model suggested a decreasing trend for rainfall from $138 \mathrm{~mm}$ to $130 \mathrm{~mm}$. $R$ squared for the cubic model was 0.4038 ; hence, it represents or explains about $40 \%$ of the data.

Better models for this data were developed by fitting the data for 1901-1960 to a quadratic polynomial using Microsoft Excel curve fitting tool. The model had $\mathrm{R}$ squared equal to 0.8465 . Hence, the model explains about $85 \%$ of the data (Figure 8).

The data for 1960-2015 was fitted to a third order polynomial model with $\mathrm{R}$ squared equal to 0.732 (Figure 9). Hence the model; explains about $73 \%$ of the data.

Stronger models for the data for 1980-2015 were developed by modeling the data for the time periods of 1980-2000 and 2000-2015. The corresponding models are illustrated in Figure 10 and Figure 11 respectively.

The model for the period 2000-2015 (Figure 11) had R squared equal to 1 . Hence, it represented $100 \%$ of the variability in the data.

The model illustrates a rise from $127 \mathrm{~mm}$ to about $135 \mathrm{~mm}$ in 2008 , followed a drop to $130 \mathrm{~mm}$ by 2015. According to the model, Cameroun's average rainfall was expected to drop as years progressed beyond 2015.

\section{Gabon}

The difference between the maximum and the minimum rainfall data is 15 units. The data used in modeling rainfall Gabon is presented in Table 4. 
Average monthly raifall $\mathrm{mm} / 10$ years versus years

(Cameroun 1901-2015)

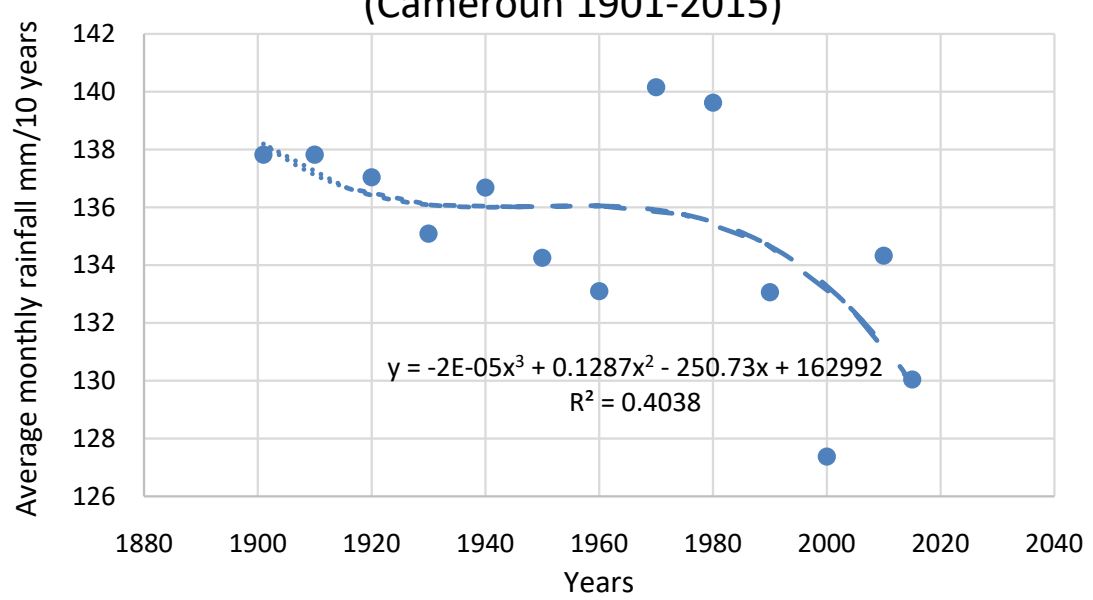

Figure 7. Variation of average rainfall mm/10 years' aggregates, Cameroun (1901-2015).

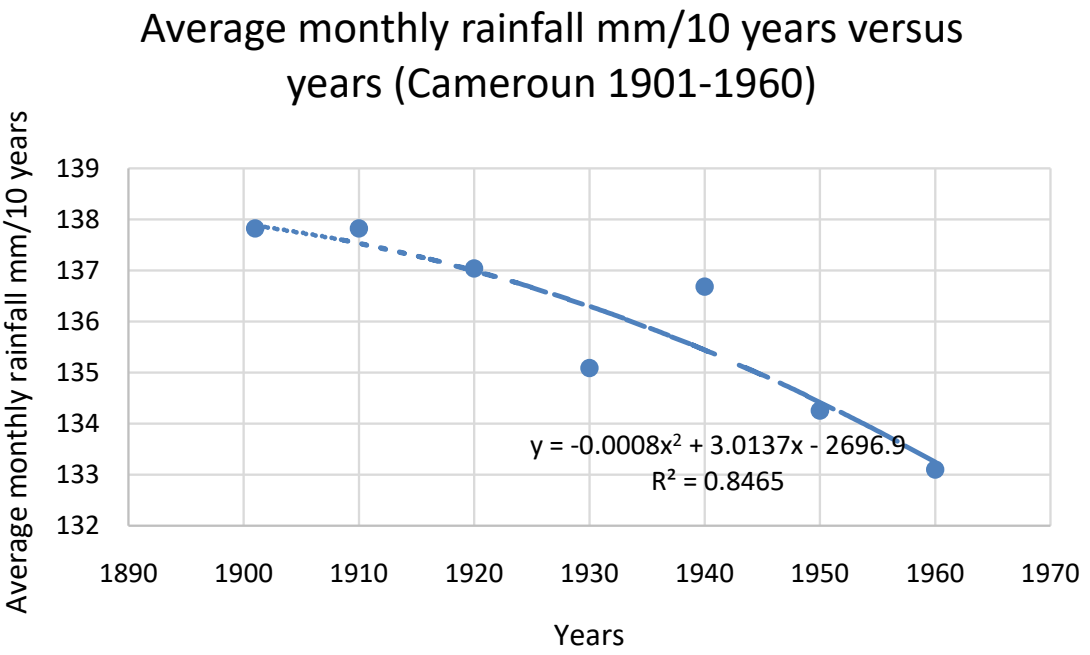

Figure 8. Variation of average rainfall mm/10 years' aggregates, Cameroun (1901-1960).

\section{Average rain fall versus years (Cameroon 1960- 2015)}

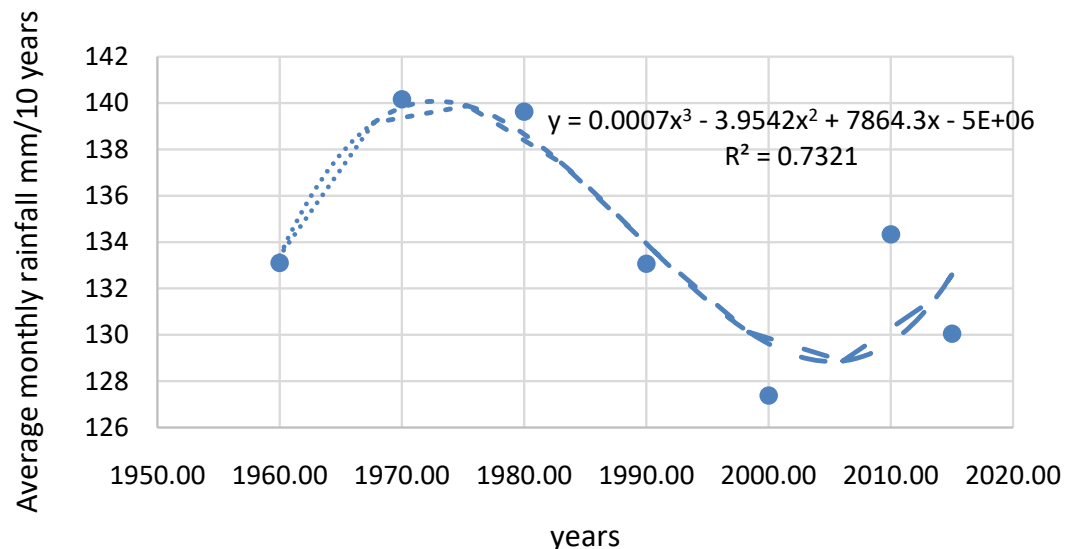

Figure 9. Variation of average rainfall mm/10 years' aggregates, Cameroun (1960-2015). 


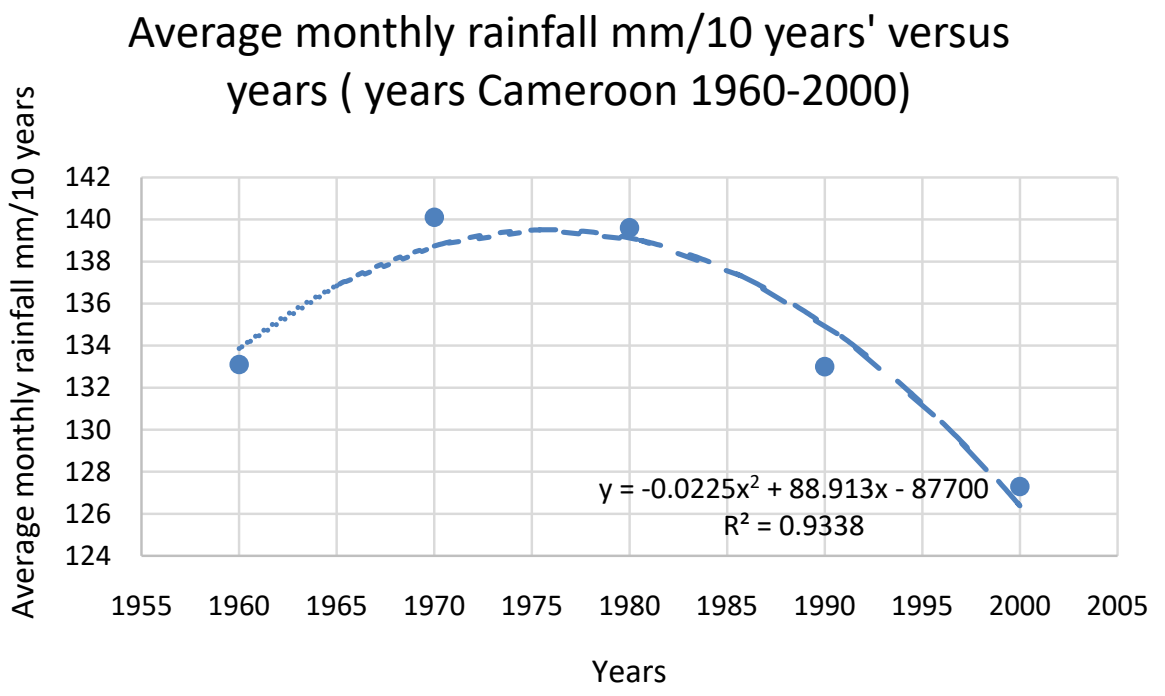

Figure 10. Variation of average rainfall mm/10 years' aggregates, Cameroun (1960-2000).

\section{Average monthly rainfall $\mathrm{mm} / 10$ years verus years (Cameroon 2000-2015)}

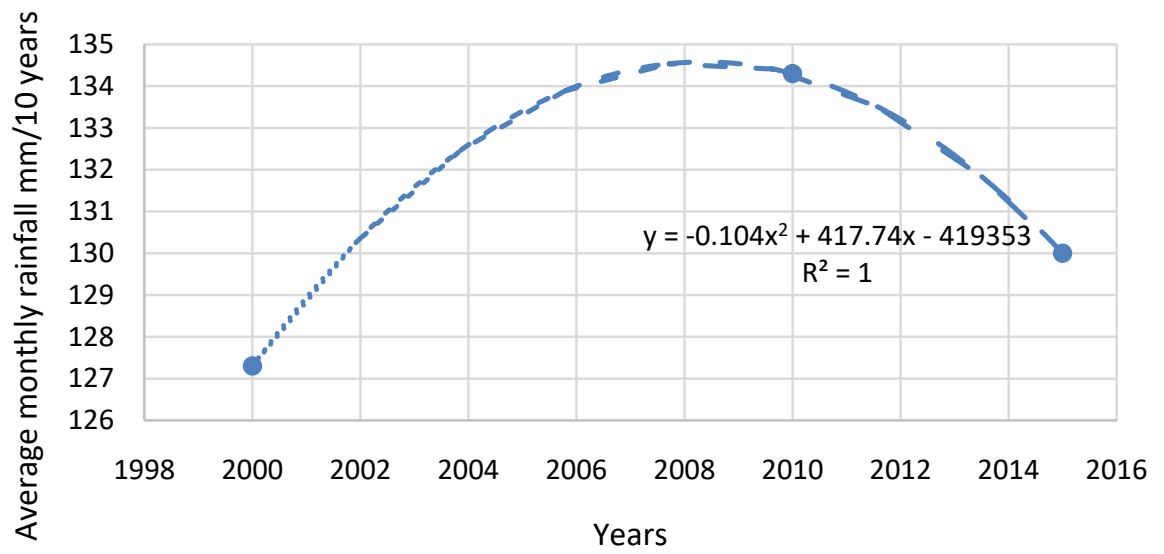

Figure 11. Variation of average rainfall mm/10 years' aggregates, Cameroun (2000-2015).

The data was fitted to a second order polynomial model using regression. Hence, the percentage increase from the minimum to the maximum temperature was $((155.5-144.4) / 144.4) \times 100=10.44 \%$. The rainfall data for Gabon from 1901-2015 follows a second order polynomial function with $R^{2}=0.5662$. The model explains about $56.6 \%$ of the variation. The model is represented as, $y=-0.0016 x^{2}+6.4385 x+6222.3$. According to this model, the average rainfall per 10 years rose from about $144 \mathrm{~mm}$ in 1901 to approximately $154 \mathrm{~mm}$ in 1970 and then dropped gradually to $152 \mathrm{~mm}$ (Figure 12).

Better models for Gabon's average rainfall were developed by modeling the data piecewise. A quadratic model was developed for average the rainfall between, 1901 and 1960. A strong model with $R^{2}=0.9155$ was developed (Figure 13). The model is represented by the following equation: $y=0.0044 \mathrm{x}^{2}-16.856 \mathrm{x}+$ 16,198 . 
Average monthly rainfall $\mathrm{mm} / 10$ years versus years

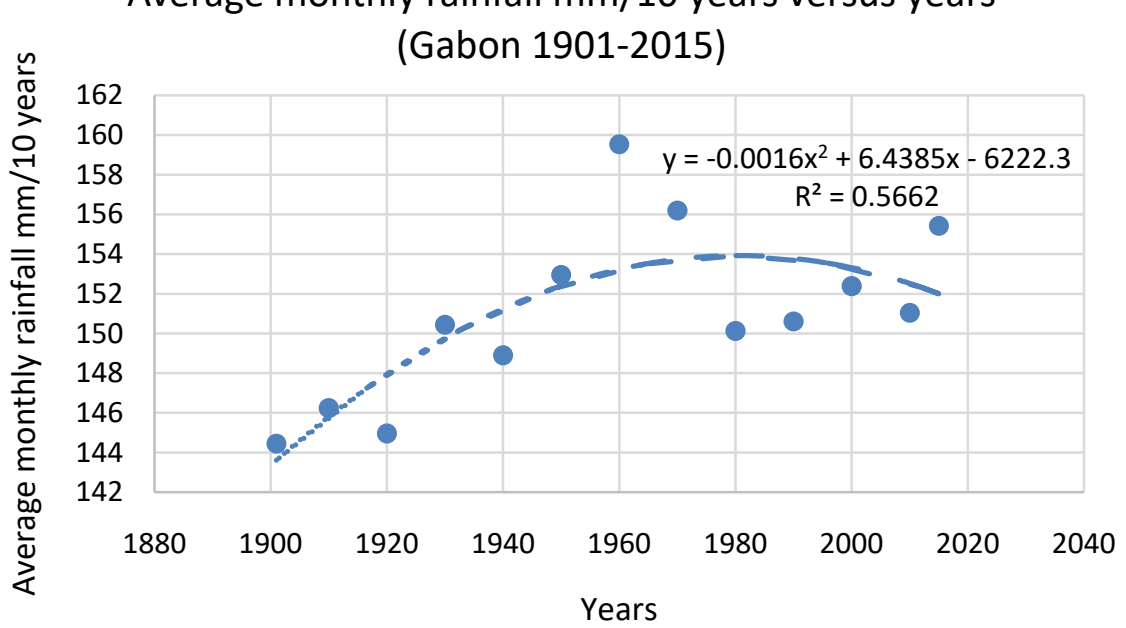

Figure 12. Second order polynomial model for average monthly rainfall $\mathrm{mm} / 10$ years' aggregates for Gabon 2005-2015.

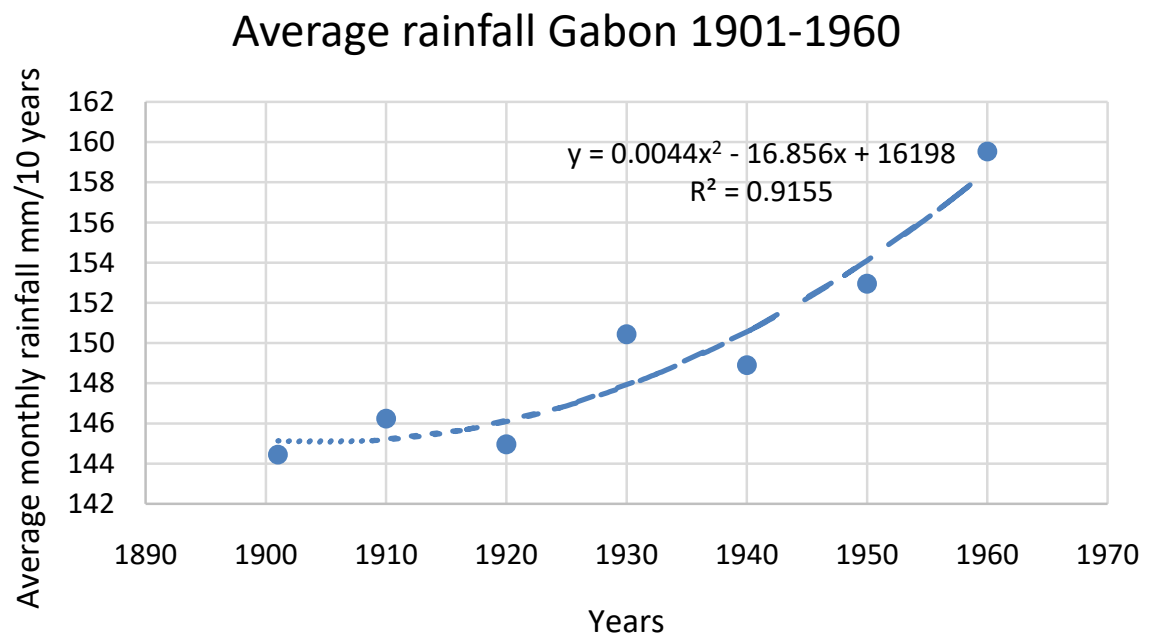

Figure 13. Second order polynomial model for average monthly rainfall mm/10 years aggregates for Gabon 1900-1960.

A quadratic model was developed for rainfall data for the period 1960-2015. The model is presented as follows. $y=0.0087 x^{2}-34.763 x+34791$, with $R^{2}=$ 0.8493 . The model explains about $85 \%$ of the average rainfall/ 10 year's variation during the period 1960-2015 (Figure 14).

Where, $y$ is the average rainfall based on every 10 consecutive years in $\mathrm{mm} /$ year and $x$ is time in years.

\section{Chad Temperature}

The difference between the maximum and the minimum average temperatures per ten-year data aggregates was $3.5^{\circ} \mathrm{C}(5.3 \mathrm{~F})$, which corresponded to a percentage rise equal to $(4.5 / 24.5)=18.36 \%$.

The average monthly temperature for Chad per 10 years is presented in Table 5. 


\section{Gabon 1960-2015}

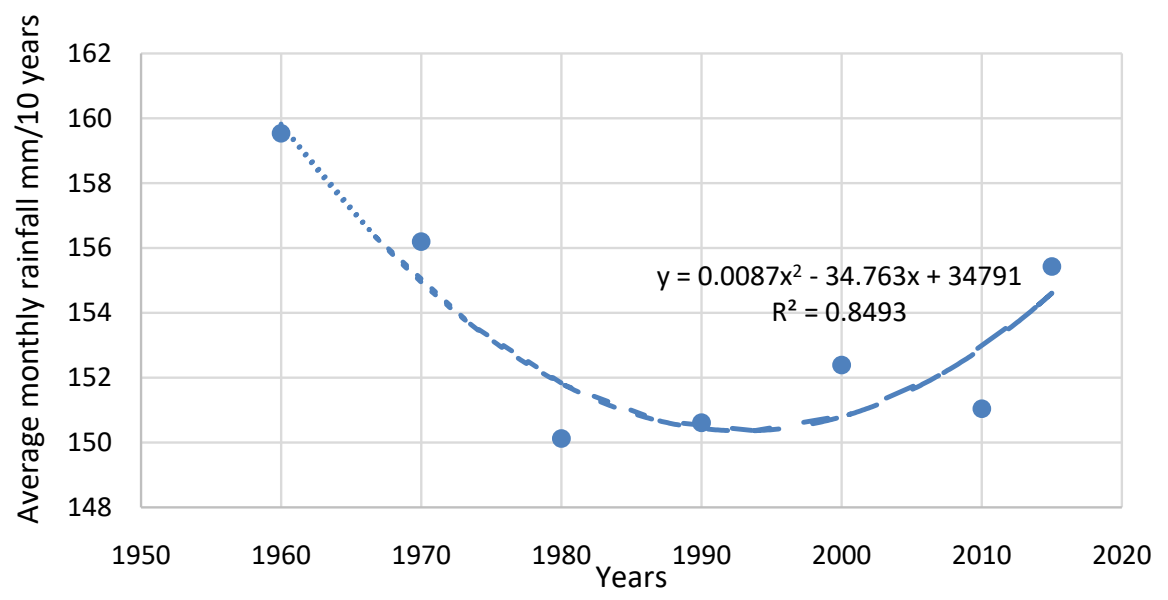

Figure 14. Second order polynomial model for average monthly rainfall $\mathrm{mm} / 10$ years aggregates for Gabon 1960-2015.

Table 5. Average monthly temperature ${ }^{\circ} \mathrm{C} / 10$ years for Chad.

\begin{tabular}{lc}
\hline Year & Average monthly temperature ${ }^{\circ} \mathrm{C} / 10$ years \\
\hline 1901 & 24.37034 \\
1910 & 26.61626 \\
1920 & 26.57028 \\
1930 & 26.66089 \\
1940 & 26.80198 \\
1950 & 26.45233 \\
1960 & 26.36165 \\
1970 & 26.39722 \\
1980 & 26.71711 \\
1990 & 26.84742 \\
2000 & 26.84741 \\
2010 & 27.85025 \\
2015 & 27.63414 \\
\hline
\end{tabular}

A correlation analysis for the average temperatures per 10 years data and was run, using SPSS 20 software. The correlation between the average temperatures per 10 consecutive years was found to be statistically significant $(\mathrm{p}=0.006)$, with coefficient of correlation being equal to $71 \%$ (Table 6).

Microsoft Excel software was used to fit a cubic model the variation between the data sets using regression. The model is given by the equation, $y=1 \mathrm{E}-05 x^{3}-$ $0.0725 x^{2}+142.07 x+23.783-92,751, R^{2}=0.8016$ (Figure 15). Where, $y$ is the average temperature based on 10 consecutive years in ${ }^{\circ} \mathrm{C} /$ year and $t$ is time in years.

According to the model, the temperature rose from an initial approximate 
Table 6. Correlation table for the mean temperature per consecutive 10 years versus years (Chad).

\begin{tabular}{|c|c|c|c|}
\hline \multicolumn{4}{|c|}{ Correlations } \\
\hline & & Mean temperature & Years \\
\hline & Pearson correlation & 1 & $0.712^{\star *}$ \\
\hline \multirow[t]{3}{*}{ Mean temperature } & Sig. (2-tailed) & & 0.006 \\
\hline & $\mathrm{N}$ & 13 & 13 \\
\hline & Pearson correlation & $0.712^{\star *}$ & 1 \\
\hline \multirow[t]{2}{*}{ Years } & Sig. (2-tailed) & 0.006 & \\
\hline & $\mathrm{N}$ & 13 & 13 \\
\hline
\end{tabular}

**. Correlation is significant at the 0.01 level (2-tailed).

\section{Chad Average temperature versus years (Chad,} 1901-2015)

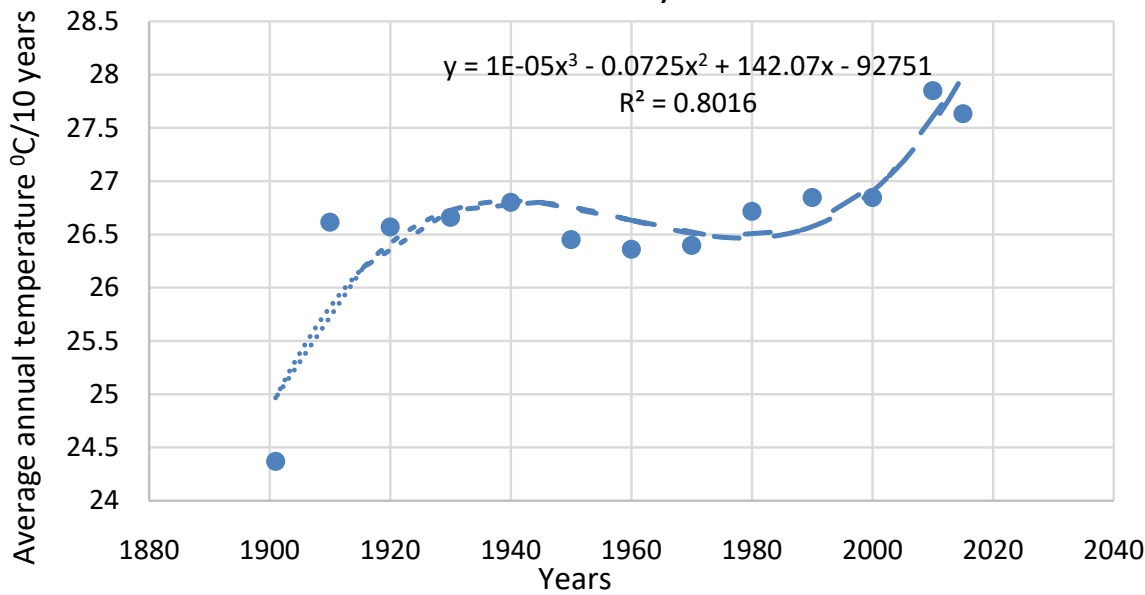

Figure 15. Variation of average monthly temperature/10 years for Chad (1901-2015).

value of just below $24.5^{\circ} \mathrm{C}$ in 1901 to almost $27^{\circ} \mathrm{C}$ in 1940 . It then marginally dropped to about $26.5^{\circ} \mathrm{C}$ in 1980 . During the period $1980-2015$ it rose to approximately $28^{\circ} \mathrm{C}$. Stronger models were developed for variation of the data through shorter time spans (1901-1950) and (1950-2015). The corresponding cubic and quadratic models had R squared (coefficients of determination) equal to, 0.907 and 0.901 respectively. These models are illustrated in Figure 16 and Figure 17 respectively

Between 1995 and 2015 the average temperature of chad rose sharply. According to the models illustrated in Figure 13 and Figure 15, the average temperature of Chad will likely rise significantly over future decades and possibly impact the environment negatively.

If the temperature continues to rise according to the model, Microsoft Excel statistical tool kit can be used to model its value by 1940 by entering 15 years in the forecasting tab. The temperature for the period 2015-2040 is illustrated in the following graph (Figure 18). The temperature by 2040 is expected to be $24.5^{\circ} \mathrm{C}$. 


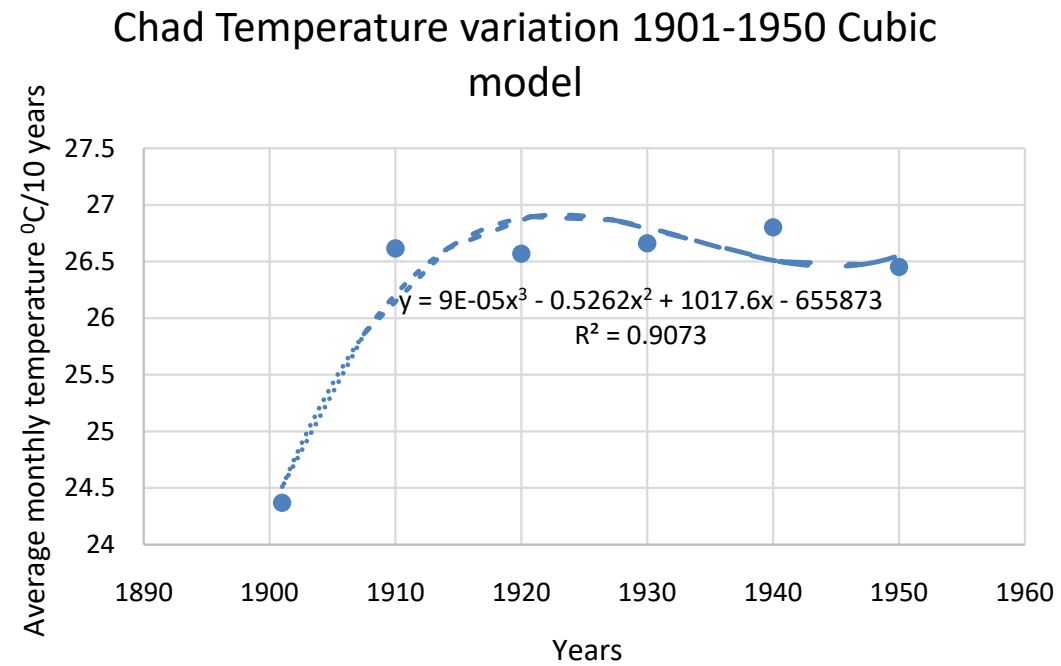

Figure 16. Chad variation of average monthly temperature/10 years for Chad (1901-1950).

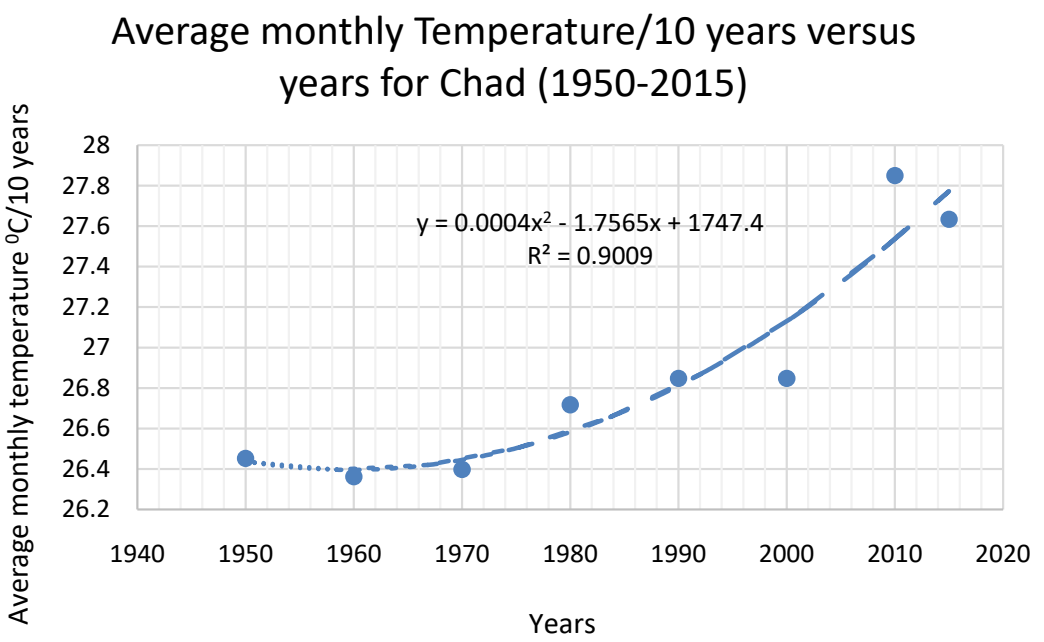

Figure 17. Chad variation of average monthly temperature/10 years for Chad (1950-2015).

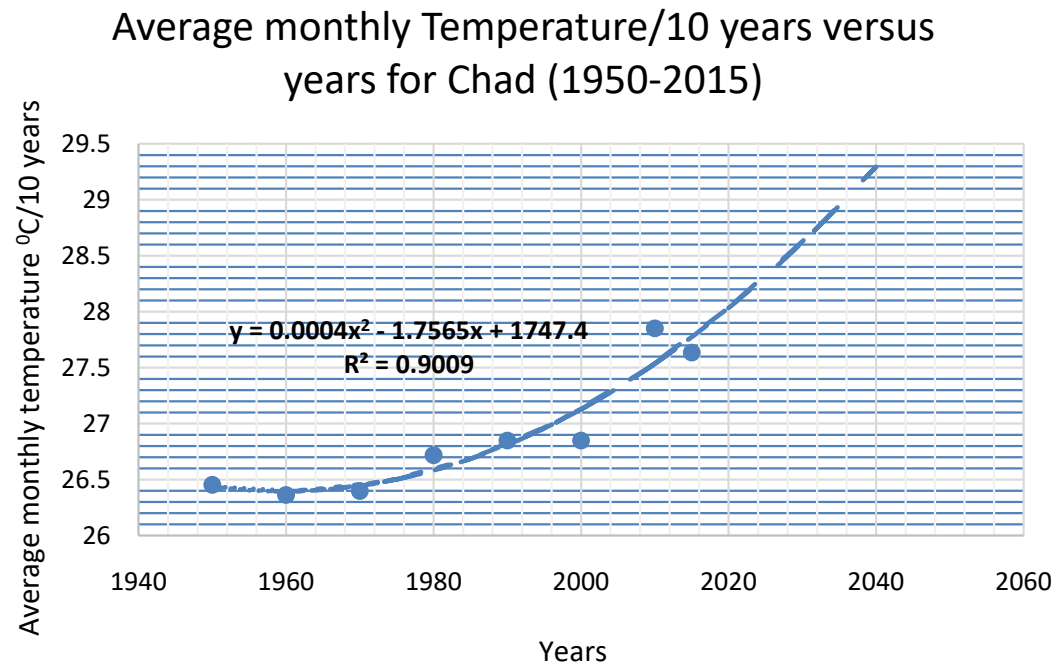

Figure 18. Chad modeling temperature for the period 2015-2040. 
The average rainfall of the Democratic Republic of Congo had a first general trend of rising, followed by a decrease to a minimum of about $123 \mathrm{~mm}$. It then rose gradually to about $127 \mathrm{~mm}$. The average rainfall for Cameroun dropped from about $138 \mathrm{~mm}$ in 1905 to $133 \mathrm{~mm}$ in 1960. It then rose to about $140 \mathrm{~mm}$ in 1980 , followed by a drop to about $139 \mathrm{~mm}$. In general, Cameroun's rainfall data tended to decrease from 1905 to 2015 (Figure 6). The average rainfall of Gabon increased to a maximum of approximately $160 \mathrm{~mm}$ according to the model illustrated in Figure 12 and then dropped to a minimum of about $150 \mathrm{~mm}$ according to the model illustrated in Figure 13. However, in general, the rainfall increased (Figure 11). The temperature of Chad was observed to rise from about $24.5^{\circ} \mathrm{C}$ to about $28^{\circ} \mathrm{C}$ from 1900 to 2015 according to a cubic model (Figure 14). Variability in climate and anthropogenic activities have impacted Lake Chad, with the former accounting for about 34\% to 45\% during the time span 1972 to 2013 [25].

\section{Policy Recommendations and Conclusion}

Anthropogenic activities such as clearing of land for agriculture, industry, slash-and-burn agriculture and other human activities in the region have an impact on the concentration of greenhouse gases which ultimately leads to global warming. Perhaps, introduction of a policy which focuses on improving national and regional environmental policies and regulations in the region would go a long way to minimize some of the anthropogenic activities especially disforestation which are very rampant in the region [26]. Similarly, since most of these forest resources are spread out in the villages and rural areas, communities should be involved in decision making process both at local, regional and the national level, so as to contribute their input in the daily management of the forest and other natural resources. Any policy directed towards managing these forest resources from the top hierarchy level without community involvement is likely to fail. Local communities have played prominent roles in addressing pressing environmental issues so as to improve ecosystems. Hence, community based environmental protection should be included in environmental protection policies [27]. Also, in most African countries, environmental degradation is driven by poverty. Policies that deal with addressing poverty and raising the income levels as well as increasing the welfare of village communities in an eco-friendly manner will help alleviate environmental degradation in the region [28]. To reduce greenhouse gas emissions and forest management, there is the need to design and build a comprehensive Regional Information Systems (RIS) in the form of periodic inventorying, monitoring and evaluation with full support of the governments in the study area. RIS would entail combining remote sensing and geographic information system (GIS) data, climate data, field survey data, land use, forest cover and forest cover change into one system. Developing such a system will offer the decision makers access to the appropriate temporal-spatial data for monitoring the pressures mounted on the areas' ecosystems and socio-economic needs. Such a tool could act as an effective decision 
support system in order to keep development in harmony with environmental sustainability, efficient land use planning and management of protected areas [29] [30].

\section{Conflicts of Interest}

The authors declare no conflicts of interest regarding the publication of this paper.

\section{References}

[1] IPCC 2007 Climate Change (2007) Climate Change Impacts, Adaptation and Vulnerability. Working Group II Contribution to the Intergovernmental Panel on Climate Change, Fourth Assessment Report, Summary for Policymakers, 23.

[2] Malcolm, J.R. and Pitelka, L.F. (2000) Ecosystems and Global Climate Change: A Review of Potential Impacts on U.S. Terrestrial Ecosystems and Biodiversity. Prepared for the Pew Center on Global Climate Change. $47 \mathrm{p}$. https://www.c2es.org/site/assets/uploads/2001/12/env ecosystems.pdf

[3] Lean, J.L. and Rind, D.H. (2008) How Natural and Anthropogenic Influences Alter Global and Regional Surface Temperatures: 1889 to 2006. Geophysical Research Letters, 35, L18701. https://doi.org/10.1029/2008GL034864

[4] The Intergovernmental Panel on Climate Change (IPCC) (2019) Climate Change and Land. An IPCC Special Report on Climate Change, Desertification, Land Degradation, Sustainable Land Management, Food Security, and Greenhouse Gas Fluxes in Terrestrial Ecosystems. 43 p.

https://www.ipcc.ch/site/assets/uploads/2019/08/4.-SPM Approved Microsite FIN AL.pdf

[5] Oppenheimer, M., Glavovic, B.C., Hinkel, J., van de Wal, R., Magnan, A.K., Abd-Elgawad, A., Cai, R., Cifuentes-Jara, M., DeConto, R.M., Ghosh, T., Hay, J., Isla, F., Marzeion, B., Meyssignac, B. and Sebesvari, Z. (2019) Sea Level Rise and Implications for Low-Lying Islands, Coasts and Communities. In: Pörtner, H.-O., Roberts, D.C., Masson-Delmotte, V., Zhai, P., Tignor, M., Poloczanska, E., Mintenbeck, K., Alegría, A., Nicolai, M., Okem, A., Petzold, J., Rama, B. and Weyer, N.M., Eds., IPCC Special Report on the Ocean and Cryosphere in a Changing Climate, 126. (In Press) https://www.ipcc.ch/site/assets/uploads/sites/3/2019/11/08 SROCC Ch04 FINAL. pdf

[6] European Commission (2020) Climate Change and Environmental Degradation. Knowledge for Policy, Foresight.

https://ec.europa.eu/knowledge4policy/foresight/topic/climate-change-environmen tal-degradation en

[7] Dai, A. (2013) Increasing Drought under Global Warming in Observations and Models. Nature Climate Change, 3, 52-58. https://doi.org/10.1038/nclimate1633

[8] Sweet, W.V., Kopp, R.E., Weaver, C.P., Obeysekera, T., Horton, R.M., Thieler, E.R. and Zervas, C. (2017) Global and Regional Sea Level Rise Scenarios for the United States. NOAA Technical Report NOS CO-OPS 083. National Oceanic and Atmospheric Administration, National Ocean Service, Silver Spring, 75 p.

https://tidesandcurrents.noaa.gov/publications/techrpt83 Global and Regional SL R Scenarios for the US final.pdf

[9] Domingues, R., Goni, G., Baringer, M. and Volkov, D. (2018) What Caused the Ac- 
celerated Sea Level Changes along the U.S. East Coast during 2010-2015? Geophysical Research Letters, 45, 13,367-13,376. https://doi.org/10.1029/2018GL081183

[10] Dunne, D. (2019) Climate Change's Impact on Soil Moisture Could Push Land past "Tipping Point". https://www.carbonbrief.org/climate-changes-impact-on-soil-moisture-could-pushland-past-tipping-point

[11] Lindsey, R. (2019) Climate Change: Global Sea Level. National Oceanic and Atmospheric Administration (NOAA), National Ocean Service, Silver Spring. https://www.climate.gov/news-features/understanding-climate/climate-change-glob al-sea-level

[12] Hausfather, Z. (2019) Explainer: How Climate Change Is Accelerating Sea Level Rise.

https://www.carbonbrief.org/explainer-how-climate-change-is-accelerating-sea-leve $\underline{\text { l-rise }}$

[13] Brunetti, M., Maugeri, M. and Nanni, T. (2000) Variations of Temperature and Precipitation in Italy from 1866 to 1995. Theoretical and Applied Climatology, 65, 165-174. https://doi.org/10.1007/s007040070041

[14] Casty, C., Wanner, H., Luterbacher, J., Esperc, J. and Bohm (2005) Temperature and Precipitation Variability in the European Alps since 1500. International Journal of Climatology, 25, 1855-1880. https://doi.org/10.1002/joc.1216

[15] Issahaku, A., Campion, B.B. and Edziyie, R. (2016) Rainfall and Temperature Changes and Variability in the Upper East Region of Ghana. Earth and Space Science, 3, 284-294. https://doi.org/10.1002/2016EA000161

[16] Toros, H., Abbasnia, M., Sagdic, M. and Tayan, M. (2017) Long-Term Variations of Temperature and Precipitation in the Megacity of Istanbul for the Development of Adaptation Strategies to Climate Change. Advances in Meteorology, 2017, Article ID: 6519856. https://doi.org/10.1155/2017/6519856

[17] Fessehaye, M., Brugnara, Y., Savage, M.J. and Brönnimann, S. (2019) A Note on Air Temperature and Precipitation Variability and Extremes over Asmara: 1914-2015. International Journal of Climatology, 39, 5215-5227. https://doi.org/10.1002/joc.6134

[18] Rosenbluth, B., Fuenzalida, H.A. and Aceituno, P. (1997) Recent Temperature Variations in Southern South America. International Journal of Climatology, 17, 67-85. https://doi.org/10.1002/(SICI)1097-0088(199701)17:1<67::AID-JOC120>3.0.CO;2G

[19] Whitfield, P.H., Bodtker, K. and Cannon, A.J. (2002) Recent Variations in Seasonality of Temperature and Precipitation in Canada, 1976-95. International Journal of Climatology, 22, 1617-1644. https://doi.org/10.1002/joc.813

[20] Mahmood, R., Pielke Sr., R.A., Hubbard, G., Niyogi, D., Dirmeyer, P.A., McAlpine, C., Carleton, A.M., Hale, R., Gameda, S., Beltran-Przekurat, A., Baker, B., McNider, R., Legates, D.R., Shepherd, M., Du, J., Blanken, P.D., Frauenfeld, O.W., Nair, U.S. and Fall, S. (2014) Land Cover Changes and Their Biogeophysical Effects on Climate. International Journal of Climatology, 34, 929-953. https://doi.org/10.1002/joc.3736

[21] Singh, O., Arya, P. and Chaudhary, B.S. (2013) On Rising Temperature Trends at Dehradun in Doon Valley of Uttarakhand, India. Journal of Earth System Science, 122, 613-622. https://doi.org/10.1007/s12040-013-0304-0

[22] Modarres, R. and da Silva, V.P. (2007) Rainfall Trends in Arid and Semi-Arid Regions of Iran. Journal of Arid Environments, 70, 344-355. 
https://doi.org/10.1016/j.jaridenv.2006.12.024

[23] Abernethy, K., Maisels, F. and White, L.J.T. (2016) Environmental Issues in Central Africa. Annual Review of Environment and Resources, 41, 1-33.

https://doi.org/10.1146/annurev-environ-110615-085415

[24] The World Bank Group (2020) Climate Change Knowledge Portal for Development Practitioners and Policy Makers.

https://climateknowledgeportal.worldbank.org

[25] Mahmood, R. and Jia, S. (2018) Analysis of Causes of Decreasing Inflow to the Lake Chad Due to Climate Variability and Human Activities. Hydrology and Earth System Sciences Discussions, 1-42. https://doi.org/10.5194/hess-2018-139

[26] Gbetnkom, D. (2005) Deforestation in Cameroon: Immediate Causes and Consequences. Environment and Development Economics, 10, 557-572. https://doi.org/10.1017/S1355770X05002330

[27] Filbin, G. (1997) Community-Based Environmental Protection: A Resource Book for Protecting Ecosystems and Communities. EPA 230-B-96-003. Office of Policy, Planning, and Evaluation, US Environmental Protection Agency, Washington DC.

[28] Olanipekun, I.O., Olasehinde-Williams, G.O. and Alao, R.O. (2019) Agriculture and Environmental Degradation in Africa: The Role of Income. Science of the Total Environment, 692, 60-67. https://doi.org/10.1016/j.scitotenv.2019.07.129

[29] Twumasi, Y.A. (2005) Park Management in Ghana Using Geographic Information Systems (GIS) and Remote Sensing Technology. Edwin Mellen Press, New York. http://mellenpress.com/book/Park-Management-in-Ghana-Using-Geographic-Info rmation-Systems-GIS-and-Remote-Sensing-Technology/6448

[30] Twumasi, Y.A., Merem, E.C., Ayala-Silva, T., Osei, A., Petja, B.M. and Alexander, K. (2017) Techniques of Remote Sensing and GIS as Tools for Visualizing Impact of Climate Change-Induced Flood in Southern African Region. American Journal of Climate Change, 6, 306-327. https://doi.org/10.4236/ajcc.2017.62016 